\title{
Metal Removal from Acid Waters by an Endemic Microalga from the Atacama Desert for Water Recovery
}

\author{
Marcela Martínez $^{1}$, Yanett Leyton ${ }^{2}$, Luis A. Cisternas ${ }^{3, *(1)}$ and Carlos Riquelme ${ }^{2}$ \\ 1 Genesis Protector Foundation (GPF), Tres Oriente 362, La Serena Golf, 1700000 La Serena, Chile; \\ mmartinez@fundaciongp.org \\ 2 Laboratorio Mesocosmos Marino, Centro de Bioinnovación de Antofagasta (CBIA), Facultad de Ciencias del \\ Mar y Recursos Biológicos, Universidad de Antofagasta, 1240000 Antofagasta, Chile; \\ yanett.leyton@uantof.cl (Y.L.); carlos.riquelme@uantof.cl (C.R.) \\ 3 Departamento de Ingeniería Química y Procesos de Minerales, Universidad de Antofagasta, \\ 1240000 Antofagasta, Chile \\ * Correspondence: luis.cisternas@uantof.cl; Tel.: +56-552637323
}

Received: 1 August 2018; Accepted: 21 August 2018; Published: 31 August 2018

\begin{abstract}
The environmental problems generated by waste from the mining industry in the mineral extraction for business purposes are known worldwide. The aim of this work is to evaluate the microalga Muriellopsis sp. as a potential remover of metallic ions such as copper $\left(\mathrm{Cu}^{2+}\right)$, $\mathrm{zinc}\left(\mathrm{Zn}^{2+}\right)$ and iron $\left(\mathrm{Fe}^{2+}\right)$, pollutants of acid mine drainage (AMD) type waters. For this, the removal of these ions was verified in artificial acid waters with high concentrations of the ions under examination. Furthermore, the removal was evaluated in waters obtained from areas contaminated by mining waste. The results showed that Muriellopsis sp. removed metals in waters with high concentrations after $4-12 \mathrm{~h}$ and showed tolerance to $\mathrm{pH}$ between 3 and 5 . These results allow proposing this species as a potential bioremediator for areas contaminated by mining activity. In this work, some potential alternatives for application in damaged areas are proposed as a decontamination plan and future prevention.
\end{abstract}

Keywords: Muriellopsis sp.; bioremediation; metallic ions; acid waters; removal

\section{Introduction}

The Atacama Desert is located in Chile, and it is also one of the aridest in the world due to its low rainfall and scarce superficial and underground water resources, and also is one of the most important mining reserves of copper, gold, silver, molybdenum and lithium in the world [1]. These geographical conditions have driven the main economic development of our country to be based on mining production. Nevertheless, as a consequence of the mining waste, there is a production of acid mine drainages (AMD) which is a leachate that results from the oxidation of sulfides exposed to water, air, bacterial activity and heavy metal compounds, that are harmful to the environment and human health.

The AMD main characteristics are [2]: (a) low $\mathrm{pH}$ values (between 2 and 5); (b) high sulfate levels (several thousand $\mathrm{mg} / \mathrm{L}$ ), iron (between 50 and $1000 \mathrm{mg} / \mathrm{L}$ ), zinc (up to $200 \mathrm{mg} / \mathrm{L}$ ), manganese (between 1 and $100 \mathrm{mg} / \mathrm{L}$ ), aluminum, lead, copper, nickel, mercury, cadmium, chromium and other toxic elements such as arsenic, and (c) high calcium and magnesium concentrations. The AMD formation begins when sulfide minerals present in coal or mine waste (such as pyrite) are exposed to air and water in mining operations [3]: Pyrite is chemically oxidized, creating a slightly acid environment suitable for the growth of some acidophilic chemoatropic microorganisms such as bacteria Acidithiobacillus ferrooxidans (formerly Thiobacillus thiooxidans). The resulting ferrous iron is 
regenerated to ferric by the action of these bacteria. The ferric ion becomes available again to oxidize more pyrite and the cycle continues once it has started. The acid solution loaded with iron goes from a sulfide-rich environment and encounter rocks, soils and waters with a higher $\mathrm{pH}(>2.5)$; in this way, the ferric iron produced is hydrolyzed and generates greater acidity [4]. This ferric ion is responsible for dissolving many heavy metal sulfide minerals such as lead, copper, zinc, and cadmium.

In Chile, the discharge of these industrial waste is regulated by Decree 90/2000 [5] which establishes the emission standard for pollutants associated with discharges of liquid waste in marine and continental waters superficial. In order to comply with this regulation, have been used for water remediation methods such as chemical precipitation, ion exchange, adsorption, membrane purification [6], passive treatments, alkalinity production systems and in the last decades biosorption processes [7-9].

Biosorption processes use plants, including algae, which have the ability to bind metallic ions in negatively charged sites [10]. Several mechanisms have been proposed to explain metal tolerance in plants. These mechanisms can be divided into two broad categories: those that involve detoxification of metallic ions within the cell and those that prevent the metal from crossing the plasma membrane [11]. From these data, it has been proposed that the ability of metals to accumulate in microalgal cells by continuous exposures of the metal contaminant would lead to mechanisms of resistance through physiological adaptive processes [12]. In some microalgae, there is a case of cross-resistance, which is when a species or population is resistant to more than one metal at the same time [13].

Microorganisms such as microalgae have demonstrated the ability to remove inorganic nutrients from wastewater such as nitrogen and phosphorus, which are assimilated for their growth [14]. Scientific support indicates the advantage of the use of microalgae in metal biosorption [15], its affinity to different metals has been recognized [16] and has been used in the remediation of metal ions [17]. For example, the use of marine algae and freshwater has been reported for the adsorption and elution of gold, silver and cobalt $[18,19]$. Based on these data, the aim of this work is to evaluate the viability of the microalgal biomass of Muriellopsis sp. to reduce the concentrations of metal ions $\left(\mathrm{Cu}^{2+}, \mathrm{Zn}^{2+}\right.$ and $\mathrm{Fe}^{2+}$ ) from acid artificial water matrixes and with high metal concentrations, and from natural waters from acid drainages obtained from areas contaminated by local mining processes. This removal could be considered as a potential alternative to mitigate the contamination of areas with mining waste.

\section{Materials and Methods}

\subsection{Obtaining Microalgal Strains}

The microalga Muriellopsis sp. was obtained from the strain collections of the Unidad de Microbiología Aplicada (UMA) at the Universidad de Antofagasta. It was cultivated in commercial liquid culture medium F/2 [20] modified and incubated at $20 \pm 1{ }^{\circ} \mathrm{C}$. It was cultivated in a 25-L Photobioreactor at $20{ }^{\circ} \mathrm{C}$ with a continuous photoperiod of $70 \mu \mathrm{E} \mathrm{m}^{-2} \mathrm{~s}^{-1}$ continuous exposure ( $24 \mathrm{~h}$ light) for 30 days.

\subsection{Metal Removal by Muriellopsis sp. from Artificial Acid Drainage (AAD)}

The AAD consisted in the simulation of water with similar characteristics to acid drainage obtained from mining waste. For this, 2 acid matrixes were established at $\mathrm{pH} 5$ and 3, standardized with $\mathrm{HCl} 0.1 \mathrm{~N}$ in $100 \mathrm{~mL}$ Erlenmeyer flasks with $50 \mathrm{~mL}$ of 35\% sterilized Marine Saline Solution (7 mg/L MgSO $4.7 \mathrm{H}_{2} \mathrm{O} ; 0.8 \mathrm{mg} / \mathrm{L} \mathrm{KCl} ; 24 \mathrm{mg} / \mathrm{L} \mathrm{NaCl}$ ). Then, $\mathrm{Cu}^{2+}, \mathrm{Zn}^{2+}$ and $\mathrm{Fe}^{2+}$ ions (Trizol of $1000 \mathrm{mg} / \mathrm{L}$, Merck) [21] were inoculated to the solutions with the aim of obtaining concentrations of 20, 50 and $100 \mathrm{mg} / \mathrm{L}$. As control 35\% marine saline solution (SSM) at pH 5 and 3 without metallic ions were used. Once the solutions were prepared, a $1.1 \times 10^{7}$ cells $/ \mathrm{mL}$ concentration of Muriellopsis sp. was added. The treatments and controls were incubated at room temperature with constant shaking to keep the sample homogenized in Shaking (JSSI-100T, JSR Corporation, Tokyo, Japan). The microalgal count was recorded at 4, 8 and $12 \mathrm{~h}$ through the Neubauer chamber with an OLYMPUS BX microscope (Olympus Corporation, Tokyo, Japan). The $\mathrm{pH}$ was measured through $\mathrm{pH}$-meter (PHS-W-LIDA, Bante 
Instruments, Shanghai, China) and the metal removal was recorded with the $\mathrm{Cu}^{2+}, \mathrm{Zn}^{2+}$ and $\mathrm{Fe}^{2+}$ kits (Spectroqant ${ }^{\circledR}$, Merck \& Company, Inc., Kenilworth, NJ, USA) using a spectrophotometer (Pharo 300, Merck \& Company, Inc., Kenilworth, NJ, USA).

\subsection{Removal of $\mathrm{Fe}^{2+}$ Ion by Muriellopsis sp. from Natural Acid Drainage (NAD)}

The NAD sample from mining waste was obtained $45 \mathrm{~km}$ northeast from Antofagasta, an area affected by mining activity (coordinates U.T.M 7,406,500-7,409,000 N and 389,000-494,500 E). At the laboratory, the sample was recorded, $\mathrm{Fe}^{2+}$ concentration with Spectroqant ${ }^{\circledR}$ Kit through a Pharo 300 spectrophotometer, $\mathrm{pH}$ (pHmeter PHS-W-LIDA) and salinity (ATAGO-ATC-S/MILL-E, ATAGO CO LTD., Tokyo, Japan). The sample was kept at room temperature.

Based on the natural parameters of metal concentration, $\mathrm{pH}$, and salinity of NAD sample from the contaminated area, 3 artificial waters were prepared as controls. For this, $100 \mathrm{~mL}$ Erlenmeyer flasks were inoculated with $30 \mathrm{~mL}$ of SSM (35\%) sterilized and acidified to pH 4 with $\mathrm{HCl} 0.1 \mathrm{~N}$. In order to obtain concentrations of 50, 100, $800 \mathrm{mg} / \mathrm{L}, \mathrm{Fe}^{2+}$ (Trisol $1000 \mathrm{mg} / \mathrm{L}$, Merck) was added. Likewise, a negative control was prepared with 35\% SSM and pH 4 without inoculating metallic ions. In parallel, $100 \mathrm{~mL}$ flasks were used with $30 \mathrm{~mL}$ of NAD as a treatment. Then, a $1.0 \times 10^{7}$ cells $/ \mathrm{mL}$ concentration of Muriellopsis sp. was added to treatments and controls. Controls and treatments were incubated at room temperature with constant shaking to keep the sample homogenized (Shaking JSR JSSI-100C/JSSI-100T). The microalgal count was recorded at 6 and $12 \mathrm{~h}$ through the Neubauer chamber with an OLYMPUS BX microscope. The $\mathrm{pH}$ was measured by $\mathrm{pH}$-meter (PHS-W-LIDA) and the metal removal was recorded with the Iron kit (Spectroqant ${ }^{\circledR}$, Merck) through a spectrophotometer (Pharo 300, Merck).

\subsection{Data Analysis}

Tests of each treatment and control were carried out in triplicate. The relation in the microalga Muriellopsis sp., of the variables of density, metal removal, and $\mathrm{pH}$ variations were evaluated through analysis of variance (ANOVA) and differences of means by multiple comparisons Tukey's, previous verification of normality and homocedasticity of data. The analysis was performed using the GraphPad PRISM 5.0 statistical software (GraphPad Software Inc., San Diego, CA, USA).

\section{Results}

\subsection{Density and Metal Removal by Muriellopsis sp. in AAD}

At the end of the treatment after 12 h., the lowest density of the microalga Muriellopsis sp., was observed in treatments of $100 \mathrm{mg} / \mathrm{L}$ in $\mathrm{pH} 5$ and $\mathrm{pH} 3$. Considering as initial inoculum $1.0 \times 10^{7}$ cells $/ \mathrm{mL}$, final values were: $\mathrm{Cu}^{2+} 7.9 \times 10^{6}$ cells $/ \mathrm{mL}$ in $\mathrm{pH} 5$ and 3 , in $\mathrm{Zn}^{2+} 8.8 \times 10^{6}$ cells $/ \mathrm{mL}$ in $\mathrm{pH} 5$ and $8.5 \times 10^{6}$ cells $/ \mathrm{mL}$ in $\mathrm{pH} 3$ and in $\mathrm{Fe}^{2+} 8.9 \times 10^{6}$ cells $/ \mathrm{mL}$ in pH 5 and $7.9 \times 10^{6}$ cells $/ \mathrm{mL}$ in $\mathrm{pH}$ 3. In addition to observing a tolerance of the microalga to survive acid $\mathrm{pH}$, an increase of $\mathrm{pH}$ in the medium was recorded at the end of the experiment. For example, the $\mathrm{pH}$ maximums observed in treatments were: in $\mathrm{Cu}^{2+} \mathrm{pH} 7.0$ (pH 5) and 6.3 (pH 3); in $\mathrm{Zn}^{2+} \mathrm{pH} 7.1$ (pH 5) and 6.7 (pH 3), and in $\mathrm{Fe}^{2+} \mathrm{pH} 7.0$ (pH 5) and 6.3 (pH 3). Unlike the other ions, in $\mathrm{Fe}^{2+}$ a decrease in $\mathrm{pH}$ was registered in the $100 \mathrm{mg} / \mathrm{L}$ concentration at the end of the experiment as $2.4(\mathrm{pH} \mathrm{5)}$ and $1.7(\mathrm{pH} 3)$. In controls (without metals) in pH 5 and 3 a maximum pH of 7.6 was registered. Finally, the microalgal survival (\%) fluctuated among the different concentrations of metals between $72-99 \%$ in pH 5 and $65-95 \%$ in pH 3 (Figures 1-3). 


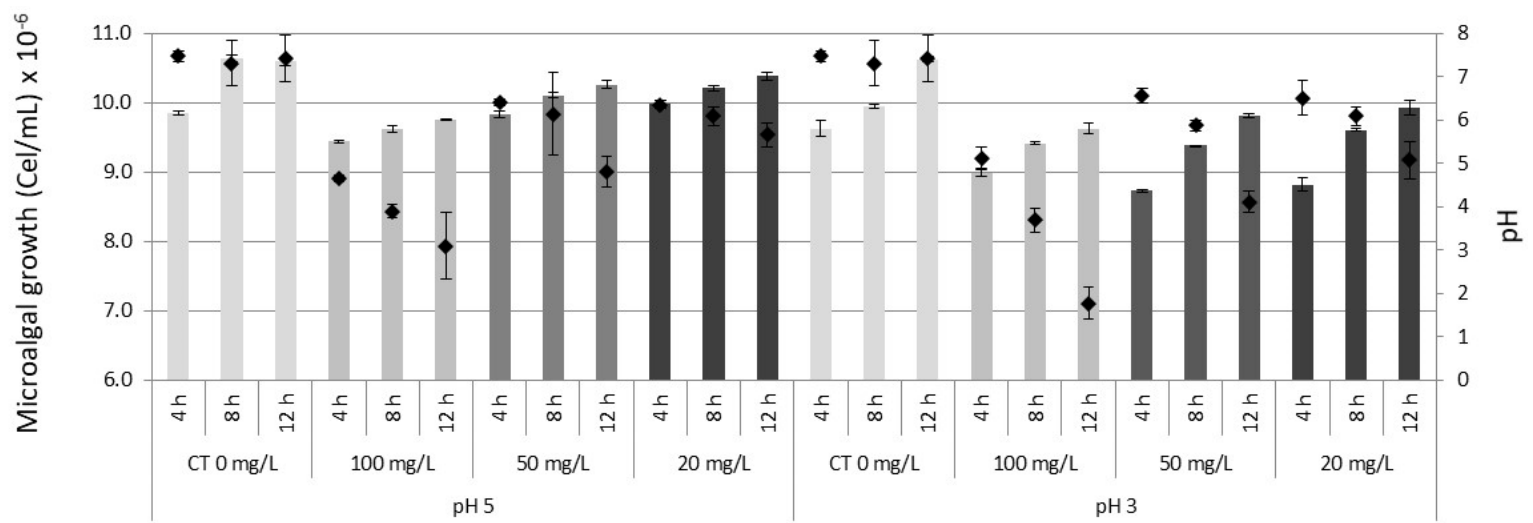

Figure 1. Growth of the microalga Muriellopsis sp., In artificial acid drainage (AAD) cultivated at different $\mathrm{pH}$ and copper concentrations. CT (Control). The bars represent \pm standard error of the mean. Diamond symbol microalgal growth.

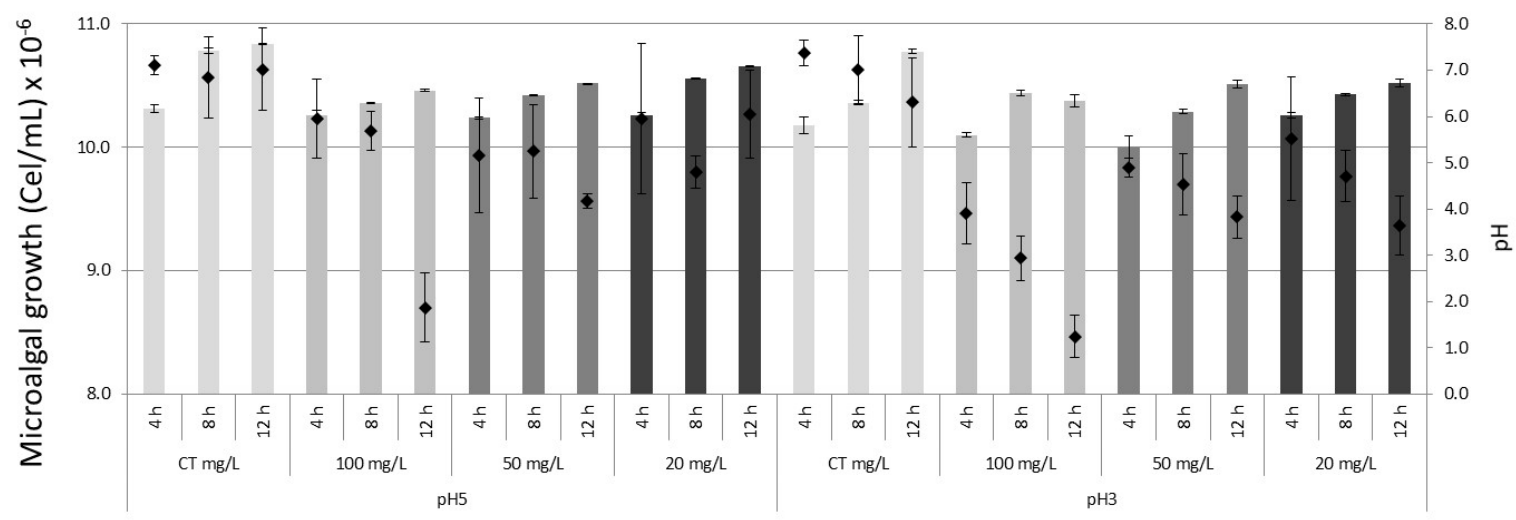

Figure 2. Growth of the microalga Muriellopsis sp. in artificial acid drainage (AAD) cultivated at different $\mathrm{pH}$ and zinc concentrations. CT (Control). The bars represent \pm standard error of the mean. Diamond symbol microalgal growth.

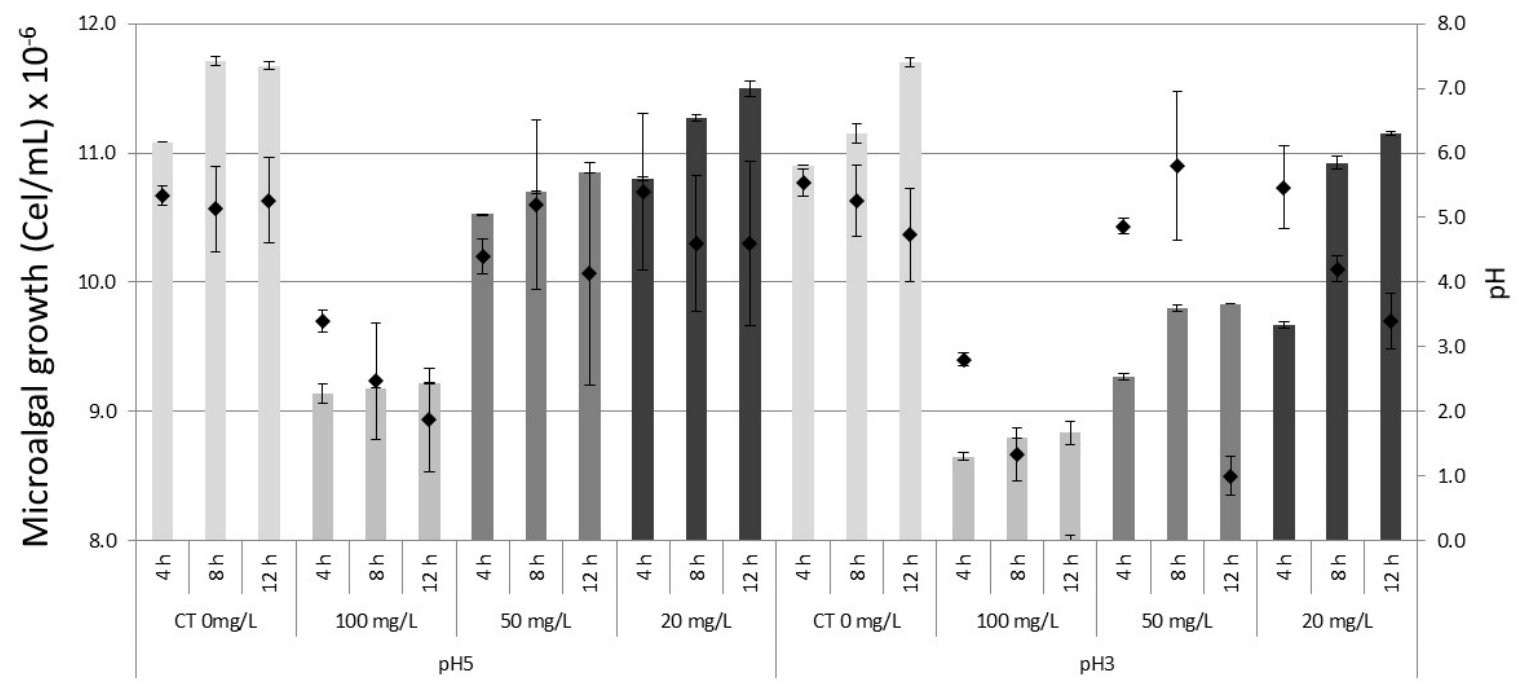

Figure 3. Growth of the microalga Muriellopsis sp. in artificial acid drainage (AAD) cultivates different $\mathrm{pH}$ and iron concentrations. CT (Control). The bars represent \pm standard error of the mean. Diamond symbol microalgal growth. 
The results showed that from 4 to $12 \mathrm{~h}$ of treatment, an increase in metal removal was observed $\left(\mathrm{Cu}^{2+}, \mathrm{Zn}^{2+}\right.$ and $\left.\mathrm{Fe}^{2+}\right)$. At $12 \mathrm{~h}$ of treatment, it was observed that the best removal in all metals was obtained in $20 \mathrm{mg} / \mathrm{L}$, in a range from minimum to maximum of 63-99.6\% in pH 3 and 84 to $99.9 \%$ in pH 5. Followed by $50 \mathrm{mg} / \mathrm{L}$ with 37.6 to $85.5 \%$ in $\mathrm{pH} 3$ and between 71.5 to $99.7 \%$ in pH 5. Finally, in $100 \mathrm{mg} / \mathrm{L}$ with $18.6-80.9 \%$ in $\mathrm{pH} 3$ and $41-93.6 \%$ in $\mathrm{pH} 5$ (Table 1). The highest percentage of removal was obtained in $\mathrm{Fe}^{2+}$ in $\mathrm{pH} 5$ and 3, this result encouraged that in samples of natural acid drainage we focused only on measuring $\mathrm{Fe}^{+2}$ removal at different concentrations.

Table 1. Copper, zinc and iron removal from AAD by the microalga Muriellopsis sp., cultivated in SSM $(35 \%)$, different $\mathrm{pHs}$ and metal concentrations. Values in parentheses are in $\mathrm{mg} / \mathrm{L}$.

\begin{tabular}{|c|c|c|c|c|c|c|c|c|c|c|c|c|c|}
\hline \multirow{2}{*}{\multicolumn{2}{|c|}{$\begin{array}{c}\text { Initial Concentration } \\
\text { Time }\end{array}$}} & \multicolumn{4}{|c|}{$20 \mathrm{mg} / \mathrm{L}$} & \multicolumn{4}{|c|}{$50 \mathrm{mg} / \mathrm{L}$} & \multicolumn{4}{|c|}{$100 \mathrm{mg} / \mathrm{L}$} \\
\hline & & $0 \mathrm{~h}$ & $4 \mathrm{~h}$ & $8 \mathrm{~h}$ & $12 \mathrm{~h}$ & $0 \mathrm{~h}$ & $4 \mathrm{~h}$ & $8 \mathrm{~h}$ & $12 \mathrm{~h}$ & $0 \mathrm{~h}$ & $4 \mathrm{~h}$ & $8 \mathrm{~h}$ & $12 \mathrm{~h}$ \\
\hline \multirow{3}{*}{$\mathrm{pH}_{3}$} & $\mathrm{Cu}^{2+}$ & $\begin{array}{c}0 \% \\
0.0)\end{array}$ & $\begin{array}{l}50.9 \% \\
(10.2)\end{array}$ & $\begin{array}{l}68.5 \% \\
(13.7)\end{array}$ & $\begin{array}{l}92.7 \% \\
(18.6)\end{array}$ & $\begin{array}{c}0 \% \\
(0.0)\end{array}$ & $\begin{array}{l}30.2 \% \\
(15.1)\end{array}$ & $\begin{array}{l}40.3 \% \\
(20.2)\end{array}$ & $\begin{array}{l}56.2 \% \\
(28.1)\end{array}$ & $\begin{array}{c}0 \% \\
(0.0)\end{array}$ & $\begin{array}{l}37.3 \% \\
(37.3)\end{array}$ & $\begin{array}{l}46.0 \% \\
(46.0)\end{array}$ & $\begin{array}{l}80.6 \% \\
(80.6)\end{array}$ \\
\hline & $\mathrm{Zn}^{2+}$ & $\begin{array}{c}0 \% \\
(0.0)\end{array}$ & $\begin{array}{c}34.7 \% \\
(6.9)\end{array}$ & $\begin{array}{l}41.8 \% \\
(8.4)\end{array}$ & $\begin{array}{l}62.2 \% \\
(12.4)\end{array}$ & $\begin{array}{c}0 \% \\
(0.0)\end{array}$ & $\begin{array}{l}16.0 \% \\
(8.0)\end{array}$ & $\begin{array}{l}32.8 \% \\
(16.4)\end{array}$ & $\begin{array}{l}37.6 \% \\
(18.8)\end{array}$ & $\begin{array}{c}0 \% \\
(0.0)\end{array}$ & $\begin{array}{l}12.3 \% \\
(12.3)\end{array}$ & $\begin{array}{l}16.2 \% \\
(16.2)\end{array}$ & $\begin{array}{l}17.8 \% \\
(17.8)\end{array}$ \\
\hline & $\mathrm{Fe}^{2+}$ & $\begin{array}{c}0 \% \\
(0.0)\end{array}$ & $\begin{array}{l}68.6 \% \\
(13.7)\end{array}$ & $\begin{array}{l}70.4 \% \\
(14.0)\end{array}$ & $\begin{array}{l}99.6 \% \\
(19.9)\end{array}$ & $\begin{array}{c}0 \% \\
(0.0)\end{array}$ & $\begin{array}{l}59.5 \% \\
(29.7)\end{array}$ & $\begin{array}{l}60.7 \% \\
(30.3)\end{array}$ & $\begin{array}{l}85.2 \% \\
(42.6)\end{array}$ & $\begin{array}{c}0 \% \\
(0.0)\end{array}$ & $\begin{array}{l}8.4 \% \\
(8.4)\end{array}$ & $\begin{array}{l}17.6 \% \\
(17.5)\end{array}$ & $\begin{array}{l}47.2 \% \\
(47.2)\end{array}$ \\
\hline \multirow{3}{*}{$\mathrm{pH}_{5}$} & $\mathrm{Cu}^{2}$ & $\begin{array}{c}0 \% \\
(0.0)\end{array}$ & $\begin{array}{l}78.8 \% \\
(15.8)\end{array}$ & $\begin{array}{l}80.6 \% \\
(16.1)\end{array}$ & $\begin{array}{l}89.7 \% \\
(17.9)\end{array}$ & $\begin{array}{c}0 \% \\
(0.0)\end{array}$ & $\begin{array}{l}66.4 \% \\
(33.2)\end{array}$ & $\begin{array}{l}68.8 \% \\
(34.4)\end{array}$ & $\begin{array}{l}71.0 \% \\
(35.5)\end{array}$ & $\begin{array}{c}0 \% \\
(0.0)\end{array}$ & $\begin{array}{l}46.8 \% \\
(46.8)\end{array}$ & $\begin{array}{l}57.5 \% \\
(57.5)\end{array}$ & $\begin{array}{l}79.0 \% \\
(79.0)\end{array}$ \\
\hline & $\mathrm{Zn}^{2+}$ & $\begin{array}{c}0 \% \\
(0.0)\end{array}$ & $\begin{array}{l}59.2 \% \\
(11.8)\end{array}$ & $\begin{array}{l}82.6 \% \\
(16.5)\end{array}$ & $\begin{array}{l}83.7 \% \\
(16.7)\end{array}$ & $\begin{array}{c}0 \% \\
(0.0)\end{array}$ & $\begin{array}{l}33.6 \% \\
(16.8)\end{array}$ & $\begin{array}{l}70.0 \% \\
(35.0)\end{array}$ & $\begin{array}{l}74.4 \% \\
(37.2)\end{array}$ & $\begin{array}{c}0 \% \\
(0.0)\end{array}$ & $\begin{array}{l}30.3 \% \\
(30.3)\end{array}$ & $\begin{array}{l}38.1 \% \\
(38.1)\end{array}$ & $\begin{array}{l}40.4 \% \\
(40.4)\end{array}$ \\
\hline & $\mathrm{Fe}^{2+}$ & $\begin{array}{c}0 \% \\
(0.0)\end{array}$ & $\begin{array}{l}76.6 \% \\
(15.3)\end{array}$ & $\begin{array}{l}88.7 \% \\
(17.7)\end{array}$ & $\begin{array}{l}100 \% \\
(20.0)\end{array}$ & $\begin{array}{c}0 \% \\
(0.0)\end{array}$ & $\begin{array}{l}90.3 \% \\
(45.2)\end{array}$ & $\begin{array}{l}90.7 \% \\
(45.4)\end{array}$ & $\begin{array}{l}99.7 \% \\
(49.8)\end{array}$ & $\begin{array}{c}0 \% \\
(0.0)\end{array}$ & $\begin{array}{l}62.0 \% \\
(62.0)\end{array}$ & $\begin{array}{l}92.7 \% \\
(92.7)\end{array}$ & $\begin{array}{l}93.5 \% \\
(93.5)\end{array}$ \\
\hline
\end{tabular}

The ANOVA statistical analysis performed to compare effects between the measured variables ( $\mathrm{pH}$ variation, density, and metal removal) indicated statistically significant differences between the variables in $\mathrm{Cu}^{2+}(\mathrm{F}-$ statistic or $\mathrm{F}=662.4, p$ value or $p<0.0001), \mathrm{Zn}^{2+}(\mathrm{F}=1235, p<0.0001)$ and $\mathrm{Fe}^{2+}$ $(\mathrm{F}=666, p<0.0001)$. The analysis of means differences by Tukey's multiple comparisons revealed that in metals, the microalga density was influenced by the $\mathrm{pH}$ of the culture medium, observing significant differences $(p<0.001)$. In addition, the $\mathrm{pH}$ variation recorded at the end of the experiment was not significant $(p<0.001)$ between $\mathrm{pH} 5$ and $\mathrm{pH} 3$ in all treatments with metals. Furthermore, no significant differences were observed in the microalgae density obtained at the end of the experiment at both $\mathrm{pH}$ in all treatments with metals. Regarding removal, the statistical analysis indicated that it is related to the microalgae density in the samples at $\mathrm{pH} 5$ and $\mathrm{pH} 3$ when significant differences were observed between these variables $(p<0.001)$. However, metal removal from the microalgae is not related to the $\mathrm{pH}$ of the culture medium, as there are no significant differences between these variables.

\subsection{Density and Metal Removal by Muriellopsis sp. in NAD}

The collected NAD from a contaminated area presented an orange color, with $\mathrm{pH} 4$, salinity of $35 \%$ and a concentration of $\mathrm{Fe}^{2+}$ of $80 \mathrm{mg} / \mathrm{L} \pm 0.1 \mathrm{mg} / \mathrm{L}$. At the end of the treatment after $12 \mathrm{~h}$ and considering as initial inoculum $1.0 \times 10^{7}$ cells $/ \mathrm{mL}$, the lowest density of the microalga Muriellopsis sp. in AAD was observed in $800 \mathrm{mg} / \mathrm{L}$ with $2.7 \times 10^{6}$ cells $/ \mathrm{mL}$ and in NAD $8.7 \times 10^{6}$ cells $/ \mathrm{mL}$ was registered. Considering $\mathrm{pH} 4$ as an initial value, it was observed that the microalga presented a tendency to increase the $\mathrm{pH}$ of the medium, registering 8.7 in control, $\mathrm{pH} 4.7$ in AAD $50 \mathrm{mg} / \mathrm{L}$, and $\mathrm{pH}$ $4.6 \mathrm{in} \mathrm{NAD} 80 \mathrm{mg} / \mathrm{L}$. However, there was a tendency to lower the $\mathrm{pH}$ in AAD of $100 \mathrm{mg} / \mathrm{L}$ (pH 3.1) and $800 \mathrm{mg} / \mathrm{L}(\mathrm{pH} \mathrm{1)}$. Finally, the microalgal survival percentage fluctuated between $28 \%$ (AAD $800 \mathrm{mg} / \mathrm{L}$ ) and 127\% (control) (Figure 4). The results of the removal showed that from $6 \mathrm{~h}$ of sampling, $\mathrm{Fe}^{2+}$ removal by the microalga was recorded in controls and treatment. The greatest removal was $71.6 \mathrm{mg} / \mathrm{L}(71.6 \%)$ in AAD $100 \mathrm{mg} / \mathrm{L}$, followed by NAD $80 \mathrm{mg} / \mathrm{L}$ with $64.5 \mathrm{mg} / \mathrm{L}(80.6 \%)$. A similar trend was recorded at the end of the treatment $(12 \mathrm{~h})$ with $91.3 \mathrm{mg} / \mathrm{L}(91.3 \%)$ in AAD $100 \mathrm{mg} / \mathrm{L}$ and $74 \mathrm{mg} / \mathrm{L}(92.5 \%)$ in NAD $80 \mathrm{mg} / \mathrm{L}$. Although in treatment of $800 \mathrm{mg} / \mathrm{L}$, the $\mathrm{Fe}^{2+}$ concentration was 
exaggerated, the recorded removal was $63.3 \mathrm{mg} / \mathrm{L}(7.9 \%)$, the result was important since the high resistance of the microalga and the effective removal could be verified (Table 2).

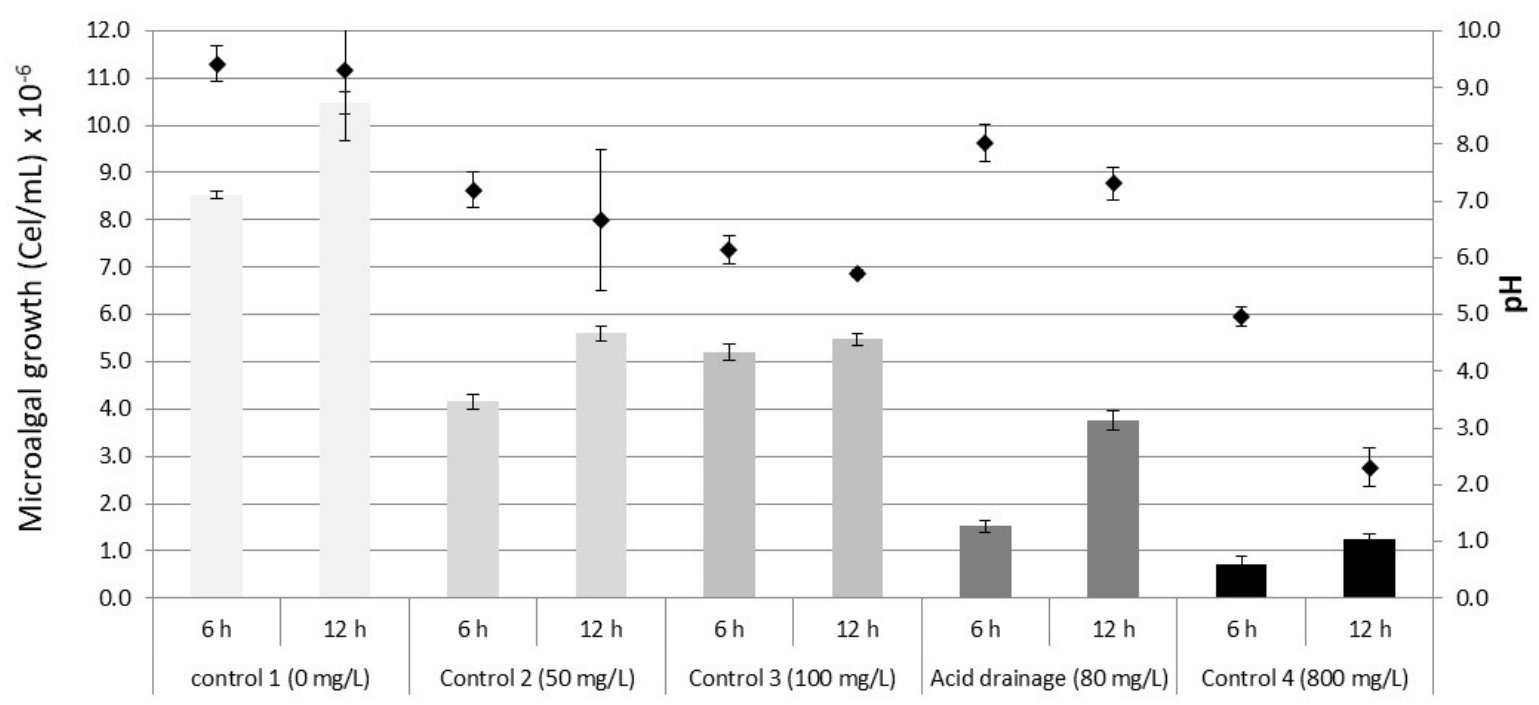

Figure 4. Growth of the microalga Muriellopsis sp. in NAD (80 mg/L of iron, pH 4 and salinity 35\%).

Diamond symbol microalgal growth. Diamond symbol microalgal growth.

Table 2. Iron removal from AAD by the microalga Muriellopsis sp.

\begin{tabular}{|c|c|c|c|c|}
\hline \multirow[b]{2}{*}{ Hours } & \multicolumn{4}{|c|}{ Initial Concentrations of $\mathrm{Fe}^{2+}$} \\
\hline & $50 \mathrm{mg} / \mathrm{L}$ & $100 \mathrm{mg} / \mathrm{L}$ & Acid Drainage $(80 \mathrm{mg} / \mathrm{L})$ & $800 \mathrm{mg} / \mathrm{L}$ \\
\hline $6 \mathrm{~h}$ & $59.9 \%(29.9 \mathrm{mg} / \mathrm{L})$ & $71.6 \%(71.6 \mathrm{mg} / \mathrm{L})$ & $80.6 \%(64.5 \mathrm{mg} / \mathrm{L})$ & $0.42 \%(0.33 \mathrm{mg} / \mathrm{L})$ \\
\hline $12 \mathrm{~h}$ & $95.6 \%(47.8 \mathrm{mg} / \mathrm{L})$ & $91.6 \%(91.6 \mathrm{mg} / \mathrm{L})$ & $92.8 \%(74.2 \mathrm{mg} / \mathrm{L})$ & $7.5 \%(6 \mathrm{mg} / \mathrm{L})$ \\
\hline
\end{tabular}

The ANOVA statistical analysis of the variables ( $\mathrm{pH}$ variation, density, and metal removal) indicated significant differences between the evaluated variables $(\mathrm{F}=82 p<0.0001)$. The analysis of means differences by Tukey's multiple comparisons revealed that the microalgae density was influenced by the $\mathrm{pH}$ from the culture medium when significant differences were observed $(p<0.001)$. Regarding the removal, the analysis indicates that the microalgae density is related to metal removal from the samples when significant differences were observed $(p<0.001)$. However, metal removal of the microalga is not related to the $\mathrm{pH}$ of the culture medium as no significant differences were observed.

\section{Discussion}

Acid mine drainages contain dissolved metals, being iron one of the main compounds of AMD [22], an important aspect to be considered is the impact caused by these discharges, since it strongly affects biodiversity (flora and fauna), both in the soil and in the water, since the acidity condition of the AMD alters the natural cycle of the affected ecosystems [9-23]. Considering the toxicity and the duration of the AMD, it is essential to prevent its formation or apply the most appropriate treatment for its mitigation and control, which must comply with the maximum acceptable limits [24], which in the case of Chile is regulated by Decree 90/2000 [5].

The aim of AAD with NAD parameters was due to the fact that we previously needed to verify if the microalga Muriellopsis sp. had the capacity to tolerate acid $\mathrm{pH}$ and remove metals from samples with high concentrations, without affecting its viability. After this analysis, this behavior was compared in NAD samples naturally contaminated by mining processes.

Regarding metal removal in AAD and NAD tests, based on Decree 90/2000 which establishes that the maximum discharge limit is $4.8 \mathrm{mg} / \mathrm{L}$ in $\mathrm{Cu}^{2+}, 1 \mathrm{mg} / \mathrm{L}$ in $\mathrm{Zn}^{2+}$ and $\mathrm{Fe}^{2+}$. In our tests, 
it was observed that Muriellopsis sp., at $12 \mathrm{~h}$ of treatment, managed to remove high concentrations of these metals. These results are preliminarily interesting to be used as potential bioremediators, since microalga Muriellopsis sp. removes metals from liquid samples in a short time, survives in high metal concentrations, and acid $\mathrm{pH}$. Tolerance tests have been carried out in other microalgae at high metal concentrations, whose results have demonstrated that they are below the tolerated concentrations by Muriellopsis sp. in our work. For example, with respect to copper, studies by Cordero (2005) [25] demonstrated that the microalga Tetraselmis chuii in LC50 tests tolerated a maximum of $6.4 \pm 3.2 \mathrm{mg} / \mathrm{L}$ of copper. In toxicity tests with Zinc, it was found that the tolerance of Selenastrum capricornut and Nannochloropsis oculata microalgae were around 0.76 and $3.22 \mathrm{mg} / \mathrm{L}$ respectively at $24 \mathrm{~h} \mathrm{[26].} \mathrm{In} \mathrm{iron,} \mathrm{Estupiñan} \mathrm{(2015)} \mathrm{[27]} \mathrm{observed} \mathrm{that} \mathrm{in} \mathrm{acid} \mathrm{drainage} \mathrm{samples} \mathrm{(} 36.9 \mathrm{mg} / \mathrm{L}$ ) from a coal mine the Chlorella Vulgaris and Scenedesmus Quadricauda microalgae managed to absorb $86.75 \%$ and $92.77 \%$. The potential of bioremediation of heavy metals, of the microalgae have been studied extensively, establishing that they are very efficient in this task. Below is a review elaborated by Zeraatkar et al., 2016 [28] (Table 3) with modifications and new references that were incorporated in this paper. 
Table 3. Heavy metal absorption capacity from different microalgal species (Modified from [28]).

\begin{tabular}{|c|c|c|c|c|c|c|c|c|}
\hline Metal & Microalgal Species & $\begin{array}{c}\text { Maximum } \\
\text { Absorption }(\mathrm{mg} / \mathrm{g})\end{array}$ & pH Optimization & $\begin{array}{c}\text { Initial Metal } \\
\text { Concentration }(\mathrm{mg} / \mathrm{L})\end{array}$ & $\begin{array}{c}\text { Biomass } \\
\text { Concentration }(g / L)\end{array}$ & $\begin{array}{c}\text { Temperature } \\
\left({ }^{\circ} \mathrm{C}\right)\end{array}$ & Time (h) & References \\
\hline $\mathrm{Al}$ (II) & Scenedesmus sp. & 0.75 & $7.68-8.61$ & 0.88 & - & - & 336 & [29] \\
\hline As (II) & Thalassiosira sp. \& Tetraselmis sp. & 0.111 & 7 & 0.13 & - & - & 0.3 & [30] \\
\hline $\mathrm{Cd}(\mathrm{II})$ & Chlorella vulgaris & 85.3 & 4 & 200 & 0.75 & 20 & 2 & [31] \\
\hline- & Chlorella sp. & 11.9 & $7.8-8$ & 20 & - & - & 1.2 & [32] \\
\hline- & Chlorella sp. & 36.4 & $7.8-8$ & 100 & - & - & 1.2 & {$[32]$} \\
\hline- & Chlorella sp. & 59.86 & $7.8-8$ & 200 & - & - & 1.2 & [32] \\
\hline- & C. vulgaris & 86.6 & 4 & 150 & 1 & 25 & - & [33] \\
\hline- & C. vulgaris & $200-250$ & - & 300 & 1 & 30 & 0.2 & [34] \\
\hline- & Chamydomonas reinhardtii & 42.6 & 6 & - & - & 25 & 1 & [35] \\
\hline- & C. Reinhardtii & 145 & 7 & 989.21 & - & 23 & - & {$[36]$} \\
\hline- & Scenedesmus obliquus & 50 & 6 & 50 & 0.6 & 30 & - & {$[37]$} \\
\hline- & S. obliquus & 12.56 & 7 & 25 & 5 & 20 & 168 & [38] \\
\hline- & S. obliquus & 25.33 & 7 & 50 & 5 & 20 & 168 & [38] \\
\hline- & S. obliquus & 50.48 & 7 & 100 & 5 & 20 & 168 & [38] \\
\hline $\mathrm{Cr}$ (III) & Chlorella miniata & 41.12 & 4.5 & 100 & - & 25 & 24 & [39] \\
\hline- & C. sorokiniana & 58.8 & 4 & - & 1 & 25 & - & [40] \\
\hline- & Scenedesmus sp. & 2.85 & $7.68-8.61$ & 3.23 & - & - & 336 & [29] \\
\hline $\mathrm{Cr}(\mathrm{VI})$ & Chlorella vulgaris & 140 & 1.5 & 250 & 1 & 25 & - & [41] \\
\hline- & Chlamydomona reinhardtii & 18.2 & 2 & - & 0.6 & 25 & 2 & [42] \\
\hline- & C. reinhardtii & 18.2 & 2 & - & 0.6 & 25 & 2 & [42] \\
\hline- & C. reinhardtii & 18.2 & 2 & - & 0.6 & 25 & 2 & [42] \\
\hline- & Dunaliella Sp. 1 & 58.3 & 2 & 100 & 1 & 25 & 72 & [43] \\
\hline- & Dunaliella Sp. 2 & 45.5 & 2 & 100 & 1 & 25 & 72 & [43] \\
\hline- & Scenedesmus inclassatulus & 4.4 & 8.9 & - & - & 25 & 24 & [44] \\
\hline- & Scenedesmus obliquus & 79.1 & - & 85.6 & - & - & 40 & [45] \\
\hline $\mathrm{Cu}(\mathrm{II})$ & Scenedesmus quadricauda & 75.6 & 5 & - & - & 22 & 120 & {$[46]$} \\
\hline $\mathrm{Cu}$ (III) & Chlorella vulgaris & 89.19 & 3.5 & - & 0.005 & 25 & 0.5 & [47] \\
\hline
\end{tabular}


Table 3. Cont

\begin{tabular}{|c|c|c|c|c|c|c|c|c|}
\hline Metal & Microalgal Species & $\begin{array}{c}\text { Maximum } \\
\text { Absorption }(\mathrm{mg} / \mathrm{g})\end{array}$ & pH Optimization & $\begin{array}{c}\text { Initial Metal } \\
\text { Concentration }(\mathrm{mg} / \mathrm{L})\end{array}$ & $\begin{array}{c}\text { Biomass } \\
\text { Concentration }(g / L)\end{array}$ & $\begin{array}{c}\text { Temperature } \\
\left({ }^{\circ} \mathrm{C}\right)\end{array}$ & Time (h) & References \\
\hline- & C. vulgaris & 14.48 & 3.5 & - & 0.1 & 25 & 0.5 & [47] \\
\hline- & C. vulgaris & 420.67 & 3.5 & 31.77 & - & 25 & 3 & [48] \\
\hline- & C. vulgaris & 714.892 & 3.5 & 31.77 & - & 25 & 3 & [48] \\
\hline $\mathrm{Hg}$ (II) & Chlamydomonas reinhardtii & 72.2 & 6 & - & - & 25 & 1 & [35] \\
\hline- & Chlorella sp. & 0.0058 & 6.2 & 0.007 & - & 28.5 & 288 & [49] \\
\hline- & Pleurococcus sp. & 0.0059 & 6.2 & 0.007 & - & 28.5 & 288 & [49] \\
\hline- & Scenedesmus sp. & 0.00455 & 6.2 & 0.007 & - & 28.5 & 288 & [49] \\
\hline $\mathrm{Ni}(\mathrm{II})$ & Chlorella miniata & 1.367 & 7.4 & - & - & - & 24 & [50] \\
\hline- & C. sorokiniana & 48.08 & 5 & 200 & 1 & 25 & 0.33 & [51] \\
\hline- & C. vulgaris & 0.641 & 7.4 & - & - & - & 24 & [50] \\
\hline- & C. vulgaris & 15.4 & 5 & 100 & 2.5 & 25 & 2 & [52] \\
\hline- & C. vulgaris & 23.47 & 5.5 & - & 0.005 & 25 & 0.5 & [47] \\
\hline- & C. vulgaris & 15.6 & 5 & 100 & 2.5 & 25 & 2 & [52] \\
\hline- & C. vulgaris & 20.23 & 5.5 & - & 0.1 & 25 & 0.5 & [47] \\
\hline- & C. vulgaris & 58.4 & 4.5 & 150 & 1 & 25 & - & [33] \\
\hline- & C. vulgaris & 59.29 & 4.5 & 5 & - & - & 1 & [47] \\
\hline- & C. vulgaris & 264.7 & 5.5 & 29.34 & 0.1 & 25 & 3 & [48] \\
\hline- & C. vulgaris & 437.84 & 5.5 & 29.34 & - & 25 & 3 & [48] \\
\hline- & Scenedesmus quadricauda & 30.4 & 5 & - & - & 22 & 120 & [46] \\
\hline $\mathrm{Pb}$ (II) & Chlamydomonas reinhardtii & 96.3 & 5 & - & - & 25 & 1 & [35] \\
\hline- & Chlorella vulgaris & $200-250$ & - & 300 & 1 & 30 & 0.2 & [34] \\
\hline- & Spirullina sp. & 41 & 4 & 50 & 0.1 & - & 0.3 & [53] \\
\hline- & Spirullina sp. & 45 & 8 & 50 & 0.1 & - & 0.3 & [53] \\
\hline- & Spirullina sp. & 5 & 2 & 100 & 0.1 & - & 0.3 & [53] \\
\hline- & Scenedesmus obliquus & 296.16 & 6.5 & 300 & 0.1 & 25 & 96 & [54] \\
\hline- & Thalassiosira sp. \& Tetraselmis sp. & 0.049 & 7 & 0.06 & - & - & 0.3 & [30] \\
\hline- & Tetraselmis suecica & 3.56 & $8.3-9.9$ & 5 & - & $21.1-22.5$ & 168 & [55] \\
\hline
\end{tabular}


Table 3. Cont.

\begin{tabular}{|c|c|c|c|c|c|c|c|c|}
\hline Metal & Microalgal Species & $\begin{array}{c}\text { Maximum } \\
\text { Absorption (mg/g) }\end{array}$ & pH Optimization & $\begin{array}{c}\text { Initial Metal } \\
\text { Concentration }(\mathrm{mg} / \mathrm{L})\end{array}$ & $\begin{array}{c}\text { Biomass } \\
\text { Concentration (g/L) }\end{array}$ & $\begin{array}{c}\text { Temperature } \\
\left({ }^{\circ} \mathrm{C}\right)\end{array}$ & Time (h) & References \\
\hline- & Tetraselmis suecica & 1.944 & $8.3-9.9$ & 10 & - & $21.1-22.6$ & 168 & [55] \\
\hline $\mathrm{U}(\mathrm{VI})$ & Chlorella vulgaris & 14.3 & 4.4 & 23.8 & 0.76 & - & 0.08 & [56] \\
\hline- & C. vulgaris & 26.6 & 4.4 & 23.8 & 0.76 & - & 96 & [56] \\
\hline- & C. vulgaris & 27 & 4.4 & 23.8 & 0.76 & - & 96 & {$[56]$} \\
\hline $\mathrm{Zn}(\mathrm{II})$ & Scenedesmus obliquus (ACO1598) & 75 & $6-7$ & 429.6 & 0.02 & 25 & 24 & {$[57]$} \\
\hline- & S. obliqus (L) & 75 & $6-7$ & 836.5 & 0.02 & 25 & 24 & [57] \\
\hline- & S. obliqus $(L)$ & 50 & $6-7$ & 209.6 & 0.02 & 25 & 1.5 & [57] \\
\hline- & Scenedesmus quadricauda & 55.2 & 5 & - & - & 22 & 120 & [46] \\
\hline- & Spirullina sp. & 37.5 & 4 & 50 & 0.1 & - & 30 & [53] \\
\hline- & Spirullina sp. & 44.5 & 8 & 50 & 0.1 & - & 30 & [53] \\
\hline- & Spirullina sp. & 35 & 2 & 100 & 0.1 & - & 30 & [53] \\
\hline
\end{tabular}


Regarding $\mathrm{pH}$ in the test with $\mathrm{AAD}$, it was observed that in most cases it tended to rise in the culture medium. This can be explained because due to photosynthesis, the microalgae produce bicarbonate $\left(\mathrm{HCO}_{3}{ }^{-}\right)$and carbonates $\left(\mathrm{CO}_{3}{ }^{2-}\right)$ [58] which could be basifying the culture medium. With the exception of the iron controls (NAD test) in treatments of 100 and $800 \mathrm{mg} / \mathrm{L}$, the pH decreased coinciding with the decrease in the microalgal density that was probably affected by the high copper concentrations and as a consequence prevented that these regulate $\mathrm{pH}$. This fall could also have occurred because the ion's standard solution is dissolved in sulfuric acid, which provides the solution with $\mathrm{Fe}^{2+}, \mathrm{SO}_{4}{ }^{2-}, \mathrm{H}^{+}$that upon exposure to water and oxygen generates oxidation, producing an increase in acidity [24]. In the NAD treatment $(80 \mathrm{mg} / \mathrm{L})$ the tendency to raise the $\mathrm{pH}$ ranged from 4.0 to 4.5. Likewise, since it is a natural sample, it is probable that other dissolved solids or its components interfere in the development of the microalga to regulate $\mathrm{pH}$, although the absorption of the microalga was not affected.

\section{Conclusions}

Our results allow us to conclude that the microalga Muriellopsis sp. can survive $12 \mathrm{~h}$ exposed to acid $\mathrm{pH}$ (between 3 and 5), to high concentrations of metallic ions up to $100 \mathrm{mg} / \mathrm{L}$ in $\mathrm{Cu}^{2+}, \mathrm{Zn}^{2+}$ and $800 \mathrm{mg} / \mathrm{L}$ in $\mathrm{Fe}^{2+}$. This is the first work that reports the tolerance of the microalga Muriellopsis sp. to parameters similar of acid drainages in mining. Based on these results, we propose the microalga Muriellopsis sp. as a potential bioremediator of waters contaminated by mining processes. As a biotechnological application, reactors could be used which allow the entry of contaminated water that will be inoculated with microalgae for a period of $12 \mathrm{~h}$, then the treated water will be separated by precipitation (in our tests we have been able to observe qualitatively that the microalga without agitation has the capacity to precipitate in a short time). Another treatment alternative is the use of raceway pools with contaminated waters which could be inoculated with the microalgae Muriellopsis sp. as a treatment. Parallel to field work, it is important to conduct a more specific studies that identify the feasibility of applying this treatment system at an industrial scale.

Author Contributions: M.M. and Y.L. performed the experiments; M.M., Y.L., L.A.C. and C.R. formulated the hypotheses, reviewed and analyzed the results, and formulated the conclusions; M.M., Y.L., and L.A.C. wrote the paper.

Funding: This research was funded by CONICYT through PAI program grant number ACM 170005.

Conflicts of Interest: The authors declare no conflict of interest.

\section{References}

1. Verdugo Gallegos, L.A. Remoción de Iones Sulfato y Metales Pesados Desde Soluciones Acuosas que Simulan Aguas de Mina Usando Mezcla de Cal, Silicatos Nano-Estructurados y Policloruro de Aluminio en una Celda DAF. Bachelor's Thesis, Universidad De Chile, Santiago, Chile, 2013. (In Spanish)

2. Murcia, E.; Trillos, C. Estudio Cinético para la Predicción de la Formación de Drenajes Ácidos en Minas de Carbon; Technical Report; Universidad Industrial de Santander, Escuela de Ingeniería Química: Bucaramanga, Colombia, 2000; pp. 5-20. (In Spanish)

3. Leusmary, D.; Villafrades, R. Remoción de Fe y Mn Provenientes de Drenajes Ácidos de Minas de Carbón Utilizando Algas y Plantas Acuáticas; Technical Report; Universidad Industrial de Santander, Escuela de Ingeniería Química: Bucaramanga, Colombia, 2001; pp. 74-76. (In Spanish)

4. Laverde, D. Prevención de la Contaminación por Drenajes Ácidos de Minas de Carbon; Technical Report; Informe final presentado a Colciencias-Minercol: Bucaramanga, Colombia, 2001; pp. 18-28. (In Spanish)

5. Presidencia, S.G.D.L. Normas de Emisión para la Regulación de Contaminantes Asociados a las descargas de Residuos Líquidos a Aguas Marinas y Continentales Superficiales. Available online: http:/ /www.siss. gob.cl/586/w3-article-4127.html (accessed on 1 August 2018).

6. Chen, J.P.; Hong, L.; Wu, S.N.; Wang, L. Elucidation of interactions between metal ions and Ca alginate-based ion-exchange resin by spectroscopic analysis and modeling simulation. Langmuir 2002, 18, 9413-9421. [CrossRef] 
7. Hedin, R.S.; Nairn, R.W.; Kleinmann, R.L.P. Passive Treatment of Coal Mine Drainage; Technical Report; US Dept of the Interior, Bureau of Mines: Washington, DC, USA, 1994.

8. Díaz, A.; Arias, J.; Gelves, G.; Maldonado, A.; Laverde, D.; Pedraza, J.; Escalante, H. Biosorción de Fe, Al y Mn de Drenajes Ácidos de Mina de Carbón Empleando Algas Marinas Sargassum sp. en Procesos Continuos; Technical Report; Revista Facultad de Ingeniería Universidad de Antioquia: Medellín, Colombia, 2003. (In Spanish)

9. Devia Torres, D.; Cáceres Sepúlveda, S.; Roa, A.L.; Suárez Gelvez, J.H.; Urbina Suárez, N.A. Use of microalgae of Chlorophyta division in the biological treatment of acid drains of coal mines. Rev. Colomb. Biotecnol. 2017, 19, 95-104. (In Spanish)

10. Macfie, S.M.; Welbourn, P.M. The cell wall as a barrier to uptake of metal ions in the unicellular green alga Chlamydomonas reinhardtii (Chlorophyceae). Arch. Environ. Contam. Toxicol. 2000, 39, 413-419. [CrossRef] [PubMed]

11. Cumming, J.R.; Taylor, G.J. Mechanisms of metal tolerance in plants: Physiological adaptations for exclusion of metal ions from the cytoplasm. In Stress Responses in Plants: Adaptation and Acclimation; Alscher, R.G., Cumming, J.R., Eds.; Wiley-Liss: New York, NY, USA, 1990.

12. Belfore, N.M.; Anderson, S.L. Effects of contaminants on genetic patterns in aquatic organisms: A review. Mutat. Res. 2001, 489, 97-122. [CrossRef]

13. Gupta, D.K.; Sandalio, L.M. Metal Toxicity in Plants: Perception, Signaling and Remediation; Springer: Berlin/Heidelberg, Germany, 2012. [CrossRef]

14. Alvarez, H.M. Biorremediación de ambientes contaminados con hidrocarburos: Un proceso complejo que involucra múltiples variables. Rev. Quím. Viva 2015, 14, 18-25. (In Spanish)

15. Kumar-Gupta, S.; Ahmad-Ansari, F.; Shriwastav, A.; Kumar-Sahoo, N.; Rawat, I.; Bux, F. Dual Role of Chlorella sorokiniana and Scenedesmus obliquus for Comprehensive Wastewater Treatment and Biomass Production for Bio-fuels. J. Clean. Prod. 2015, 115, 255-264. [CrossRef]

16. Doshi, H.; Seth, C.; Ray, A.; Kothari, I.L. Bioaccumulation of heavy metals by green algae. Curr. Microbiol. 2008, 56, 246-255. [CrossRef] [PubMed]

17. Volesky, B. Biosorption of Heavy Metals; CRC Press: Boca Raton, FL, USA, 1990; pp. 7-14.

18. Hamdy, A.A. Biosorption of heavy metals by marine algae. Curr. Microbiol. 2000, 41, 232-238. [CrossRef] [PubMed]

19. Fujita, T.; Kuzuno, E.; Mamiya, M. Adsorption of metal ions briver algae. Bunseki Kagaku 1992, 108, $123-128$.

20. Guillard, R.R.L.; Ryther, J.H. Studies of marine planktonic diatoms: I. Cyclotella Nana Hustedt, and Detonula Confervacea (CLEVE) Gran. Can. J. Microbiol. 1962, 8, 229-239. [CrossRef] [PubMed]

21. Toral, M.; Lara, N.; Gomez, J.; Richter, P. Determinación de hierro en fase sólida por espectrofotometría derivada de segundo orden. Bol. Soc. Chil. Quím. 2001, 46, 51-60. (In Spanish) [CrossRef]

22. De la Cruz, C.E. Mitigación de drenaje ácido en minas subterráneas aplicando fangos artificiales. Caso: Mina Orcopampa. Revista del Instituto de Investigación de la Facultad de Ingeniería Geológica, Minera, Metalúrgica y Geográfica 2006, 9, 69-74. (In Spanish)

23. Leal, L.T.C. Drenajes Ácidos de Mina Formación y Manejo. Rev. ESAICA 2015, 1, 53-57. (In Spanish) [CrossRef]

24. Montesinos León, M.I. Caracterización de Afluentes de Mina para Elección de la Alternativa Óptima de Tratamiento. Ph.D. Thesis, Pontificia Universidad Católica del Perú, Lima, Peru, 2017. (In Spanish)

25. Cordero, J.; Guevara, M.; Morales, E.; Lodeiros, C. Efecto de metales pesados en el crecimiento de la microalga tropical Tetraselmis chuii (Prasinophyceae). Rev. Biol. Trop. 2005, 53, 325-330. (In Spanish) [CrossRef] [PubMed]

26. Santo, G.E. Efectos Agudos y Crónicos de Diversos Metales en una Batería de Organismos Dulceacuícolas. Ph.D. Thesis, Universidad Autónoma de Aguas Calientes, Aguascalientes, México, 2013. (In Spanish)

27. Estupiñan, J.C. Evaluación de un Tratamiento para Drenaje Ácido Proveniente de una Mina de Carbon. Bachelor's Thesis, Universidad de La Sabana, Chía, Colombia, 2015. (In Spanish)

28. Zeraatkar, A.K.; Ahmadzadeh, H.; Talebi, A.F.; Moheimani, N.R.; McHenry, M.P. Potential use of algae for heavy metal bioremediation, a critical review. J. Environ. Manag. 2016, 181, 817-831. [CrossRef] [PubMed]

29. Pérez-Silva, K.R.; Vega-Bolaños, A.M.; Hernández-Rodríguez, L.C.; Parra-Ospina, D.A.; Ballen-Segura, M.Á. Uso de scenedesmus para la remoción de metales pesados y nutrientes de aguas residuales de la industria textil. Ingeniería Solidaria 2016, 12, 95-105. (In Spanish) [CrossRef] 
30. Jaramillo Ramos, R.A.; Romero Jara, H.M. Tratamiento de las Aguas del Sector las Katyas del Estero el Macho en Machala Mediante la Thalassiosira y Tetraselmis. Bachelor's Thesis, Universidad Técnica de Machala, Machala, Ecuador, 2018. (In Spanish)

31. Aksu, Z. Equilibrium and kinetic modelling of cadmiun (II) biosorption by C. Vulgaris in a batch system: Effect of temperatura. Sep. Purif. Technol. 2001, 21, 285-294. [CrossRef]

32. Ortega, P.; Yomaira, B.; Valdez Álvarez, C.A. Análisis de Remoción de Cadmio por Acción de la Microalga Chlorella sp. Inmovilizada en Perlas de Alginate. Bachelor's Thesis, Universidad Politécni Ca Salesiana, Quito, Ecuador, 2017. (In Spanish)

33. Aksu, Z.; Dönmez, G. Binary biosorption of cadmiun (II) and nickel (II) onto dried Chlorella vulgaris: Co-ion effect on mono-component isotherm parameters. Process Biochem. 2006, 41, 860-868. [CrossRef]

34. Gaber, E.; Yahia, A.; Abdulrahim, A. Biosorption of Cadmium and Lead from Aqueous Solutions by Chlorella vulgaris Biomass: Equilibrium and Kinetic Study. Arab. J. Sci. Eng. 2014, 39, 87-93.

35. Tüzün, I.; Bayramoglu, G.; Yalcin, E.; Basaran, G.; Anca, M.Y. Equilibrium and kinetic studies on biosorption of $\mathrm{Hg}$ (II), Cd (II) and $\mathrm{Pb}$ (II) ion sonto microalgae Chlamydomonas reinhardtii. J. Environ. Manag. 2005, 77, 85-92. [CrossRef] [PubMed]

36. Adhiya, J.; Cai, X.; Sayre, R.T.; Traina, S.J. Binding of aqueour cadmium by the lyophilized biomass of Chlamydomonas reinhardtii. Colloid Surf. A-Physicochem. Eng. Asp. 2002, 210, 1-11. [CrossRef]

37. Chen, C.Y.; Chang, H.W.; Kao, P.C.; Pan, J.L.; Chan, J.S. Biosorption of cadmium by $\mathrm{CO}_{2}$-fixing microalga Scenedesmus obliquus CNW-N. Bioresour. Technol. 2012, 105, 74-80. [CrossRef] [PubMed]

38. Amézquita Imata, E.E. Remoción de Cadmio Bivalente $\left(\mathrm{Cd}^{+2}\right)$ Mediante Bioadsorción en un Sistema de Flujo Continuo Empacado con Biomasa Muerta e Inmovilizada de Scenedesmus Obliquus (Turpin) Kützing 1833 a Escala de Laboratorio. Bachelor's Thesis, Universidad Nacional De San Agustin De Arequipa, Arequipa, Peru, 2018. (In Spanish)

39. Han, X.; Wong, Y.S.; Tam, N.F.Y. Surface complexation mechanism and modeling in Cr (III) biosorption by a microalgal isolate, Chlorella miniata. J. Colloid Interface Sci. 2006, 303, 365-371. [CrossRef] [PubMed]

40. Akthar, N.; Iqbal, M.; Zafar, S.I.; Iqbal, J. Biosorption characterisitics of unicelular Green alga Chlorella sorokinian immobilized in loofa sponge of removal of Cr (III). J. Environ. Sci. 2008, 20, 231-239.

41. Gokhale, S.V.; Jyoti, K.K.; Lele, S.S. Kinetic and equilibrium modeling of chromium (VI) biosorption on fresh and spent Spirulina platensis/Chlorella vulgaris biomass. Bioresour. Technol. 2008, 99, 3600-3608. [CrossRef] [PubMed]

42. Arica, M.Y.; Tüzün, I.; Yalcin, E.; Ince, O.; Bayramoglu, G. Utilisation of native, heat and acid-treated microalge Chlamydomonas reinhardtii preparations for biosorption of $\mathrm{Cr}$ (VI) ions. Process Biochem. 2005, 40, 2351-2358. [CrossRef]

43. Dönmez, G.; Aksu, Z. Removal of chromium (VI) from saline wastewaters by Dunaliella species. Process Biochem. 2002, 38, 751-762. [CrossRef]

44. Jácome-Pilco, C.R.; Cristiani-Urbina, E.; Flores-Cotera, L.B.; Velasco-García, R.; Ponce-Noyola, T.; Cañizares-Villanueva, R.O. Continuous Cr (VI) removal by Scenedesmus incrassatulus in an airlift photobioreactor. Bioresour. Technol. 2009, 100, 2388-2391. [CrossRef] [PubMed]

45. Quezada, R.; Varela, E.; Rosa, M.A. Remediación natural para completar la depuración del cromo (VI) en efluentes de curtiembres. In Proceedings of the Quinto Congreso Deficiencia y Tecnología para Alumnos, Simposio Llevado a cabo en el Congreso de la Facultad Regional de Villa María, Córdoba, Argentina, 15-16 de Agosto 2012. (In Spanish)

46. Bayramoğlu, G.; Yakup Arıca, M. Construction a hybrid biosorbent using Scenedesmus quadricauda and Ca-alginate for biosorption of $\mathrm{Cu}$ (II), Zn (II) and Ni (II): Kinetics and equilibrium studies. Bioresour. Technol. 2009, 100, 186-193. [CrossRef] [PubMed]

47. Mehta, S.K.; Gaur, J.P. Removal of $\mathrm{Ni}$ and $\mathrm{Cu}$ from single and binary metal solutions by free and immobilized Chlorella vulgaris. Eur. J. Protistol. 2001, 37, 261-271. [CrossRef]

48. Mehta, S.K.; Tripathi, B.N.; Gaur, J.P. Enhanced sorption of $\mathrm{Cu}^{2+}$ and $\mathrm{Ni}^{2+}$ by acid-pretreated Chlorella vulgaris from single and binary metal solutions. J. Appl. Phycol. 2002, 14, 267-273. [CrossRef]

49. Vela García, F.N. Remoción de Mercurio en Aguas Residuales de la Actividad Minera con el Uso de Microalgas. Bachelor's Thesis, Universidad de las Américas, Quito, Ecuador, 2016. (In Spanish)

50. Wong, J.P.K.; Wong, Y.S.; Tam, N.F.Y. Nickel biosorption by two Chlorella species, C. vulgaris (a comercial species) and C. Miniata (a local isolate). Bioresour. Technol. 2000, 73, 133-137. [CrossRef] 
51. Akthar, N.; Iqbal, J.; Iqbal, M. Removal and recovery of nickel (II) from aqueous solution by loofa sponge-immobilized biomass of Chlorella sorokiniana: Characterization studies. J. Hazard. Mater. 2004, $108,85-94$

52. Al-Rub Abu, F.A.; El-Naas H, M.; Benyahia, F.; Ashour, I. Biosorption of nickel on blank alginate beads, free and immobilized algal cells. Process Biochem. 2004, 39, 1767-1773. [CrossRef]

53. Aneja, R.K.; Chaudhary, G.; Ahluwalia, S.S.; Goyal, D. Biosorption of $\mathrm{Pb}^{2+}$ and $\mathrm{Zn}^{2+}$ by Non-Living Biomass of Spirulina sp. Indian J. Microbiol. 2010, 50, 438-442. [CrossRef] [PubMed]

54. Villanueva Vega, J.A. Determinación de la Biorremocion de Plomo $\left(\mathrm{pb}^{+2}\right)$ Mediante Hongos y Microalgas Nativas Aisladas de Efluentes Industriales Empacadas en un Sistema en Serie de Agitación Continua. Bachelor's Thesis, Universidad Nacional de San Agustin de Arequipa, Arequipa, Peru, 2015. (In Spanish)

55. Mendoza Espinoza, S. Efecto de las Concentraciones de Plomo en el Crecimiento de la Microalga Marina Tetraselmis Suecica. Bachelor's Thesis, Universidad Nacional del Santa, Nuevo Chimbote, Peru, 2017. (In Spanish)

56. Vogel, M.; Gunther, A.; Rossberg, A.; Li, B.; Bernhard, G.; Raff, J. Biosorption of U (VI) by the Green algae Chlorella vulgaris in dependence of $\mathrm{pH}$ value and cell activity. Sci. Total Environ. 2010, 409, 384-395. [CrossRef] [PubMed]

57. Monteiro, C.; Castro, P.L.; Xavier Malcata, F. Biosorption of zinc ions from aqueous solution by the microalga Scenedesmus obliquus. Environ. Chem. Lett. 2011, 9, 169-176. [CrossRef]

58. Sobczuk, T.M. Influencia de las Condiciones Hidrodinámicas y de la Fracción Molar de $\mathrm{CO}_{2}$ en la Fase Gaseosa Sobre el Crecimiento Celular en Cultivos de Microalgas. Ph.D. Thesis, Universidad De Almería, Almería, Spain, 2005. (In Spanish)

(C) 2018 by the authors. Licensee MDPI, Basel, Switzerland. This article is an open access article distributed under the terms and conditions of the Creative Commons Attribution (CC BY) license (http:/ / creativecommons.org/licenses/by/4.0/). 